\title{
Relações intertextuais na família Renoir: tal pai, tal filho?
}

\author{
Sandra Regina Ramalho e Oliveira \\ Universidade do Estado de Santa Catarina
}

\begin{abstract}
Resumo
Neste artigo discute-se a intertextualidade, objeto teórico, tendo como objeto empírico a relação entre as obras do pintor impressionista Pierre-Auguste Renoir e as de seu filho, o cineasta do realismo poético francês, Jean Renoir. Os dados foram preferencialmente obtidos na exposição Renoir Père et Fils, apresentada no Musée D'Orsay, em Paris, de 6 de novembro de 2018 a 27 de janeiro de 2019. Após revisitar a biografia de cada um desses expoentes da arte, foram analisadas brevemente as oito salas da mostra do D'Orsay, destacando as relações entre pai e filho, bem como as extrapolações dessas influências, trazendo outros artistas e escritores cujas obras foram articuladas na obra de Jean Renoir. Por fim, são apresentadas algumas problematizações.
\end{abstract}

Palavras-chave: Intertextualidade. Pintura. Cinema. Pierre-Auguste Renoir. Jean Renoir. Leitura de Imagens.

\section{O fenômeno intertextual}

Analisar e discutir o fenômeno linguístico da intertextualidade traz duas outras questões estéticas e éticas para exame: a originalidade da obra, seja ela literária, visual, musical, cinematográfica, teatral ou outra; e a autoria como propriedade de um criador sobre sua criação. Como se pode perceber, ambas as questões estão interligadas pois, contestada a originalidade por plágio, ou citação, paráfrase, paródia ou outra categoria de intertextualidade em relação a um texto anterior, paralelamente, a autoria está sendo colocada em xeque.

A arte contemporânea está entremeada de produções intertextuais, como modo mesmo de questionar a arte, artistas ou trabalhos anteriores a ela. Mas a arte de tempos atrás também se nutriu de narrativas anteriores a ela, pois basta lembrar os casos óbvios das relações entre as produções clássicas gregas e romanas, ao ponto de hoje referenciar-se a uma arte grecoromana; e o caso da retomada de alguns padrões pré-históricos no modernismo, como mostra, entre outros, Ana Claudia de Oliveira, em seu estudo Neolítico: Arte Moderna (1987), título que já antecipa os achados da investigação.

Se os fenômenos intertextuais em si se dão a partir de um período impreciso, embora ancestral, os estudos sobre as relações entre obras diferentes podem ter como marco fundador dois momentos distintos, o primeiro demarcado pelo linguista russo Mikhail Bakhtin (1895-1975), que data do início do século XX, com a proposição do conceito de dialogia; e o 
outro, postulado pela também linguista, a búlgaro-francesa Julia Kristeva (1941-...), integrante do grupo de intelectuais franceses que se reuniam em torno da revista Tel Quel, ou seja, "tal qual", expressão que em francês ou português apontam para a intertextualidade. No seio desse grupo, em grande atividade em meados do século $\mathrm{XX}$, Kristeva partiu do conceito bakhtiniano de dialogia e lhe conferiu características distintas, inaugurando o termo - e o respectivo conceito - de intertextualidade (intertextualité, em francês), delimitando um campo teórico destinado ao estudo de relações entre textos.

Necessário se faz destacar que, como em diversos outros objetos de estudo do âmbito das linguagens, as investigações sobre a intertextualidade estão mais desenvolvidas no campo do verbal do que em outras expressões linguísticas. Nessa produção teórica da linguagem verbal, assim sendo, os investigadores de outras linguagens, como as visuais, buscam analogias, ou também intertextualidades, para fundamentar e examinar a potência do fenômeno intertextual, as mudanças que se operam de texto para texto, de linguagem para linguagem, de época para época, de cultura para cultura. E como e porque elementos formais são reapresentados; ou como e porque temas são retomados, com outros investimentos expressivos.

Transitando num panorama geral entre os pensadores que se ocuparam deste fenômeno linguístico, encontra-se em Bakhtin (FIORIN, 2008), como desdobramento da sua noção de dialogia, a ideia que todo enunciado é repercussão de uma manifestação anterior, exceto a primeira fala de um suposto Adão mítico, tido aqui como uma figura metafórica.

Por seu turno, Roland Barthes (2002, p. 59) na mesma direção, afirma que a intertextualidade é inerente a todo texto, qualquer que seja ele; e, importante se faz sublinhar, Barthes defende que não se trata de uma questão de filiação teórica, uma vez que "o intertexto é um campo geral de fórmulas anônimas, cuja origem é raramente recuperável, citações inconscientes ou automáticas, dadas sem aspas". E Julia Kristeva reitera: "todo texto se constrói como um mosaico de citações, todo texto é a absorção e transformação de outro texto" (2002, p. 54-57).

Mais recentemente, Gérard Genette (1930-2018) outro estudioso das relações entre textos, afirma em um artigo derivado de sua obra mater Palimpsestos (2002, p. 68-73), intitulado "A transtextualidade ou a intertextualidade redefinida", que todas as obras são derivadas de uma obra anterior, por transformação ou por imitação. Genette cunhou o termo transtextualidade como continente de cinco tipos específicos de intertextualidade - ou transtextualidade - e é peremptório ao afirmar que "um texto pode sempre ler um outro, e assim por diante, até o fim dos textos".

Assim, a postura do senso comum que tende a desvalorizar uma versão de algum fato textual anterior perde o seu crédito e passa a exigir um exame mais minucioso para buscar outros fatores implicados que não apenas alguma semelhança, nas aparências ou nas 
essências, no plano de expressão ou no plano de conteúdo, ou no campo formal ou no campo semântico.

No caso em questão, o que determina as semelhanças? Vivências comuns aos dois criadores de imagens? Dando vida a imagens outrora imóveis, estaria Jean Renoir tentando suplantar a sombra do pai famoso? Ou seria uma homenagem a ele? Kristeva afirma que a introdução da noção de intertextualidade nos estudos linguísticos é claramente orientada para a questão do sentido e da interpretação, sentidos como lugar de uma interação complexa entre diferentes textos (2002, p. 55). Assim sendo, no campo linguístico, propriamente, o que se pode depreender em apenas uma visita a uma exposição de arte?

\section{A proposta de uma exposição}

Justapor a obra de dois expoentes de duas linguagens diferentes, a pintura e o cinema, foi a proposta do Musée D'Orsay, em Paris, em cartaz de 6 de novembro de 2018 a 27 de janeiro de 2019. Tanto o pintor teve uma produção marcante para a arte do seu tempo, como o cineasta e ator para o seu; ou mesmo, ambos, para a história da arte e para a história do cinema.

Entretanto, em boa parte de sua carreira o cineasta foi até marginalizado, não obstante ter reconhecida sua obra no decorrer do tempo, sendo agora considerado como um clássico de uma linguagem que se constituía entre o entretenimento e a arte.

Pierre-Auguste Renoir (1841-1919) nasceu, viveu e morreu na França, enquanto que o filho, Jean Renoir (1894-1979), viveu entre a França e os Estados Unidos, onde morreu, tendo lá vivido altos e baixos, finalmente sendo reconhecido, aos 84 anos com um Oscar.

O conceito curatorial da mostra do Orsay se concentrou nas coincidências entre 0 trabalho dos dois produtores de manifestações no caso do primeiro uma obra exclusivamente visual; e uma trajetória voltada a diversos modos de atuação na linguagem audiovisual, no caso do segundo. Nenhuma inovação, até aí, no que se refere a uma exposição propondo um diálogo entre dois artistas, o que costuma apontar para intertextualidades.

Mas o que há de novo e instigante é o fato de se tratar de pai e filho: Pierre-Auguste Renoir, pintor impressionista, e Jean Renoir, cineasta e ator, entre outros papéis. E que a grande questão que perseguiu a vida e a obra de Jean Renoir foi exatamente a influência do pai, dito de outro modo, a busca de uma identidade pessoal de Jean, ao mesmo tempo respeitando, admirando e lutando para se desvincular da obra do pai.

A partir deste eixo curatorial, já evidenciado no título, Renoir père et fils, ou seja, Renoir Pai e Filho, a mostra foi desdobrada em oito salas, cada qual com uma temática específica.

Não se deve esquecer, todavia, que além de seu pai, ou exatamente proporcionado por ele, Jean conviveu com relevantes artistas visuais e escritores, em uma época fervilhante e fecunda para as ideias e seus diversos modos de expressão em Paris, na primeira metade do século XX. 
Para que se possa refletir sobre as inter-relações entre a obra de pai e filho, necessário se faz, antes de relatar aspectos trazidos pela exposição, revisitar questões relacionadas a cada um deles.

\section{Renoir Pai}

Pierre-Auguste Renoir, um dos mais relevantes impressionistas franceses, nasceu em Limoges em 25 de fevereiro de 1841 e morreu em Cagnes-sur-Mer, no sul da França, em 3 de dezembro de 1919.

O impressionismo, movimento e estilo nascido em Paris e exaustivamente explorado, dispensa apresentações; e Renoir, o pai, é considerado por alguns o próprio criador desse movimento artístico, embora seu nome seja derivado do título de um quadro de Monet, Impression, soleil levant (Impressão, nascer do sol). Não é demais lembrar, entretanto, que se trata do movimento modernista que inaugurou o desprendimento da retratação fiel da realidade, diluindo em pinceladas os efeitos de luz sobre paisagens e figuras humanas. Para tanto, havia a busca de cenários e cenas ao ar livre; e o sul da França, dada a intensidade da sua luz, era a meca dos pintores impressionistas.

Renoir Pai vinha de família pobre, a qual se mudou para Paris em busca de oportunidades, possibilitando a Pierre-Auguste iniciar-se na pintura, decorando porcelana para uma fábrica que, ao mecanizar seus processos, dispensou-o. Começou a estudar arte, chegando a estudar na École de Beaux-Arts de Paris; conheceu os pintores Sisley e Monet, introduzindo-se no ambiente artístico, mas não tinha dinheiro sequer para comprar tinta; restava-Ihe sobreviver de pequenos trabalhos. Ainda assim, ganhou prêmio no Salon de Paris de 1868; mas o sucesso demorou a chegar.

Insistente, pintava sua companheira e modelo, Lise, e continuava buscando um conceito de beleza, retratando a natureza e mulheres, algumas nuas, como na sua série Baigneuses (Banhistas). Le Moulin de la Galette (O Moinho da Galette) foi outra obra marcante na sua trajetória, mas a consagração oficial aconteceu em 1898, quando o Governo Francês adquiriu a obra Au Piano (Ao piano). Frequentava o Salon, com altos e baixos quanto a premiações. Morava em Montmartre, onde achava motivos para suas telas, tanto quando havia encontrado anteriormente na floresta de Fontainebleau.

No início da década de oitenta, em busca de novas referências, Renoir Pai foi à Argélia em busca da luz para executar suas obras, e depois foi à Itália, onde investigou as raízes clássicas da pintura, fascinando-se com as obras do renascentista Rafael. Disto resultaram mudanças no seu trabalho, como nos contornos, que ficaram mais definidos, na introdução de mais cores frias e nas novas temáticas. Nesta década, a influência de Rafael somou-se à admiração que Pierre-Auguste já trazia consigo em relação à obra de Jean-Auguste Ingres, 
pintor neoclássico francês. Outro aspecto relacionado ao período é que Renoir deixou de pintar ao ar livre e passou a trabalhar em ateliê.

A partir da década de noventa, no entanto, houve um retorno aos nus e retratos que o notabilizaram, já que havia uma demanda de admiradores deste tipo de obra e ele tinha a família para sustentar; a propósito, foi neste período, em 1894, que nasceu seu Jean Renoir, o segundo dos três filhos do casal Jean-Pierre Renoir e Aline Charigot: Pierre, Jean e Claude. Aline havia sido sua modelo desde antes do casamento e foi sua companheira até sua morte, em 1915.

Renoir Pai adquiriu artrite reumatoide e isto alterou completamente sua vida, dadas as limitações físicas que esta moléstia impõe: mudou-se para Cagnes-sur-Mer, no sul da França, região mais quente e saudável, onde possuía casa de veraneio. E, mesmo tendo dificuldades motoras para pintar decorrentes da moléstia que o acometia, trabalhou até a morte, em 1919.

\section{Renoir Filho}

Filho de Pierre-Auguste Renoir e Aline Charigot, Jean nasceu em Paris, em 15 de setembro de 1894. Cineasta, ator, escritor e roteirista, nasceu e viveu no ambiente que tinha seu pai como astro-rei. Ao contrário de muitos filhos de personalidades geniais, observáveis ao longo da história, Jean não teve crise de identidade: não seguiu a profissão do pai, também não se voltou contra ele. Jean Renoir conseguiu se sustentar em outra atividade profissional, na época iniciante, inovadora e incipiente, tanto que muitos de seus filmes ainda foram mudos, e a grande maioria, em preto e branco. Enfrentou dificuldades, mas não abandonou o cinema e, por outro lado, nunca deixou de respeitar e admirar seu pai.

Desta relação peculiar, talvez, procurando ser diferente sem desprezar a bagagem de percepção visual, o culto a determinados padrões estéticos e a sensibilidade herdados da vida em família, resultou na obra cinematográfica que se inter-relaciona com a visualidade da pintura de seu pai e de outros artistas seus contemporâneos, aproveitando-a para construir uma narrativa própria, mas carregada de uma nostalgia atualizada.

Renoir Filho, que nasceu quando seu pai já tinha 53 anos, passou infância e juventude tranquilas, entre Paris, onde estudava em uma escola de elite, e Cagnes-sur-Mer, onde a família passava o verão e para onde mais tarde mudou-se definitivamente. Depois de estudar matemática e filosofia em Aix-en-Provence, Jean foi para a frente de batalha na Primeira Grande Guerra e retornou ferido, em 1915, mesmo ano que perdeu sua mãe. Na convalescença, interessou-se mais profundamente pelo cinema, enquanto que seu irmão mais velho, Pierre, ator de teatro, era de opinião que cinema não era uma carreira para franceses, dada a tradição literária do seu país. Era visto como uma atividade menor.

Em 1940, motivado pela invasão da França pelos nazistas e, paralelamente, pela pujança da indústria cinematográfica em Hollywood, Jean Renoir transferiu-se para os 
Estados Unidos da América. Mas foi anteriormente, quando conheceu e casou, em 1920, com a última modelo de seu pai, Andrée Heutschiling, depois Catherine Hessling, nome artístico que adotou nas películas do próprio marido, que Jean Renoir se lançou nessa profissão então considerada aventureira, embora ele a levasse muito a sério, tendo se preparado assistindo incontável número de filmes e analisando inúmeros modos de dirigi-los. O casamento perdurou dez anos, mas oficialmente durou vinte e três, sendo que em 1921 nasceu um filho desta relação, Alain. E no início dos anos quarenta, Jean iniciou uma relação com Dido Freire, filha de um diplomata brasileiro, relação esta que se transformou em casamento bemsucedido até que a morte dele os separou, em 1979.

Entre fracassos e sucessos, problemas financeiros e recuperação de patrimônio, inclusive de obras de seu pai, Jean Renoir deixou uma vasta filmografia, onde constam cerca de quarenta películas, conjunto que, além de receber um Oscar e conferir-lhe uma comenda do Governo Francês, permitiu que viesse a constar como um clássico da atividade criadora cognominada sétima arte.

Renoir Filho mantinha uma postura crítica à sociedade, manifesta em seus filmes, o que talvez tenha sido o motivo de seus iniciais insucessos, pois destoava do espírito vigente em Hollywood. Suas personagens não são estereotipadas, característica então presente no cinema norte-americano, mas são mais próximas à natureza humana e à realidade. Dada a sua sensibilidade, transferida para suas personagens, as questões sociais são tratadas atrás de problemas essencialmente pessoais, e sem maniqueísmos. Apresentava então personagens autênticas, "sem maquiagem", como ele mesmo gostava de dizer, com resultados de um naturalismo sensual e poético, em narrativas fluídas e honestas.

\section{Relações entre pai e filho}

A mostra Renoir père et fils foi dividida em oito salas, cada uma destacando um aspecto específico. A primeira sala já abordava as relações entre pai e filho com toda clareza, mas não apenas, ao apresentar trechos de filmes de Jean, obras de Pierre-Auguste e também de Alfred Sisley, uma vez que este impressionista fazia parte do círculo de amigos da família Renoir. Assim sendo, nesta sala foram apresentadas obras suas que guardam similaridade visual com a filmografia de Renoir Filho.

Mas havia outro fenômeno de intertextualidade nesta primeira sala, evidenciada no seu título, Partie de Campagne, homônimo ao filme de Jean de 1936, traduzido para o português como Um dia no Campo: trata-se de uma adaptação de uma novela igualmente homônima do escritor francês Guy de Maupassant.

Conforme o título dá conta, na literatura de Maupassant e no filme de Jean Renoir os enredos são ambientados na zona rural francesa, o campo, ou a campanha, bem como em décadas anteriores, nas margens do rio Loing onde viveu e morreu Sisley e onde o próprio 
Jean comprou uma casa, em 1922. Identifica-se, em Partie de Campagne (Um dia no campo), similaridades com quadros de Renoir pai e de Sisley, bem como possíveis cenas domésticas vivenciadas na região. Conforme a curadoria, não obstante, "o ritmo, os enquadramentos e as adições sonoras mostram que Jean inventa ali uma linguagem própria a esta arte então ainda jovem que é o cinema" (MUSÉE D’ORSAY, 2018-2019).

$\mathrm{Na}$ sala dois, intitulada La création en héritage (A criação como herança), é adicionado outro ingrediente: a cerâmica. Os trabalhos apresentados na mostra perpetuam essa linguagem tridimensional mostrando cerâmicas de Jean, numa prática também influenciada por seu pai, que se iniciou na arte pintando sobre porcelana, embora o Renoir que mais se destacou como ceramista tenha sido outro filho de Pierre-Auguste, Claude, que viveu entre 1901 e 1969 e que não deve ser confundido com outro Claude Renoir, neto de Pierre-Auguste, cineasta, que viveu entre 1913 e 1993. A sala dois também dá conta de que Jean Renoir vendeu quase todos os quadros do pai que possuía para financiar seus primeiros filmes, vindo a recomprá-los, posteriormente, na medida recuperação das suas posses.

A sala três, chamada de Modèles et portraits (Modelos e retratos) volta-se para as ligações entre pai e filho no que se refere à relação entre pintor e modelo. Foram várias as sessões de pose de Jean garoto ou adolescente, só ou acompanhado. Talvez esses momentos de intimidade com o pai e com a arte, familiarizando-o com a atividade artística, de certo modo tenham sido retribuídos quando Renoir Filho escreveu a biografia do pai, a partir de muitas anotações e fotos expostas na mostra. Entre os retratos pintados por seu pai, o preferido parece ter sido Jean en chasseur, (Jean vestido de caçador), de 1910. Esta tela acompanhou-o durante toda a vida, aparecendo no fundo de algumas de suas fotos.

A seguir, em outra sala, sob o título de Un modele en comum (Um modelo em comum) foram apresentados fotografias e cartazes de filmes de Jean, entre outros, imagens e documentos que tratavam de um importante elo de ligação entre pai e filho: Andrée Heuschling. Modelo de Renoir Pai desde 1915, Andrée casou-se em 1920 com Renoir Filho que pretendia, além de fazê-la sua esposa, torná-la uma grande atriz. Andrée adotou então outro nome mais palatável para o americanismo inerente a Hollywood: Catherine Hessling. $O$ título da sala, "Um modelo em comum", não deixa de encerrar uma ironia, e levanta uma suspeita, dada a sua ambivalência: era a modelo ou a mulher que ambos tinham em comum? Até onde se sabe, Andrée ou Catherine era modelo do pai e mulher do filho.

A quinta sala, intitulada Lieux et temps partagés: Paris et le XIXe. siècle (Lugares e tempos partilhados: Paris e o século XIX) apresentava a nostalgia de um francês que se mudara para os Estados Unidos. Na década de 50, Jean ambienta seus filmes no tempo de seu pai, em Montmartre, com seus bailes públicos e seus jovens. Entretanto, Renoir Pai não foi a única fonte de Renoir Filho, que fez uso do cancan - ou cancã - e da estética de Toulouse-Lautrec, como já havia feito com a poética de Sisley. 
A sala seguinte, a sexta, sob o título de Adapter Flaubert, Zola, Mirabeau (Adaptar Flaubert, Zola, Mirabeau), mostrava que, mesmo que nunca tenha querido trazer para a tela a vida de seu pai, Jean sempre voltava a evocar o tempo em que ele viveu e o ambiente familiar, adaptando para o cinema Flaubert, Zola, Mirabeau, escritores amigos de seu pai e que ambientavam seus romances em locais similares aos pintados por Renoir Pai. $O$ naturalismo desses autores satisfazia as intenções de Jean de fazer um cinema realista e abordando temas cotidianos.

A penúltima sala, a número sete, trazia como tema Cagnes et Le Déjeuner sur l'herbe (Cagnes e $O$ almoço sobre a grama), que abordava a realização de um filme, em 1959, cujo título reproduzia o de uma obra clássica de Manet: Le Déjeuner sur l'herbe. As filmagens foram feitas em uma propriedade da família Renoir, Collettes, em Cagnes, sul da França. Além dessas relações, enquanto outras filmagens, na época, se desenvolviam em estúdios, Jean Renoir insistia em filmar preferencialmente ao ar livre, capturando o tipo de imagem tão cara aos impressionistas. Talvez esses aspectos, nostálgicos, tenham sido os responsáveis pela incompreensão do público da época.
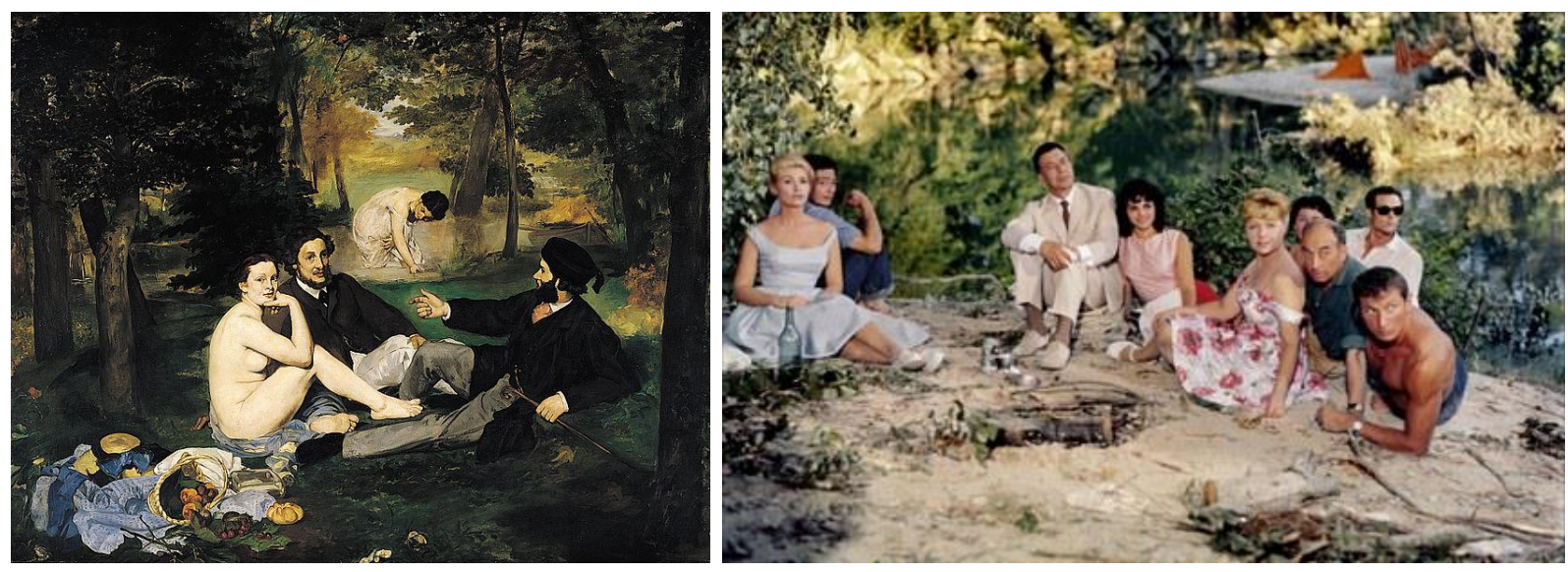

Figura 1 - Le(s) déjeuneur(s) sur l'herbe (1863), tela de Édouard Manet; cena de filme (1959) de Jean Renoir. Fonte: Wikimedia Commons. Disponível em: https://commons.wikimedia.org/wiki/File:Édouard_Manet_-_Le_Déjeuner_sur_l\%27herbe.jpg; The New Yorker. Disponível em: https://www.newyorker.com/culture/richard-brody/watching-sandy-withjean-renoir. Acesso em: fev. 2019.

A última sala, sob o título de Le Fleuve (O Rio), é homônima ao título de um filme de 1951 de Jean Renoir, com enredo adaptado de um romance de Rumer Godden, o qual foi rodado na Índia, perto de Calcutá. Sendo seu primeiro filme colorido, nele Jean se aventura no campo tão bem dominado por seu pai, o das cores. Todavia, neste filme Jean alude a Matisse e Dufy, não negando, mas discutindo sua hereditariedade. Outro cineasta, o contemporâneo, Martin Scorsese, declarou que nesse filme Jean recupera, sem hesitação, o traço dos impressionistas, sobretudo nas paisagens; mas como uma homenagem aos 
esforços para se desvincular de suas origens, o que ali se expressa, no discurso verbal e visual é também, “alguma coisa de universal” (apud Musée D’Orsay, 2018-2019).

\section{Questões e considerações}

Até que ponto ideias anteriores, registradas em palavras, sons ou imagens, podem servir de estímulo para sua atualização, sua contraposição, ou sua crítica? Até que ponto vestígios ou marcas de manifestações pré-existentes encontradas em trabalhos posteriores podem fazer com que estes sejam desqualificados ou ter o seu valor minimizado?

A exposição Renoir Pai e Filho conseguiu atingir seu intento, expresso já no título escolhido. Não seria tarefa árdua, uma vez que, entre as diversas formas de expressão desenvolvidas por Jean Renoir, cada uma mostra alguma referência intertextual à obra de seu pai. Todavia, para desenvolver aquela narrativa, a exposição, foi necessário organizar, além de quadros e filmes, também manuscritos, trajes de personagens de filmes, cartazes, peças de cerâmica e maquetes, vindos de diversos lugares, alguns estando pela primeira vez na França.

Além de tantas conexões entre pai e filho há, entre os diversos livros que Renoir Filho escreveu, um que se intitula Pierre-Auguste Renoir, mon père, de 1962, reeditado pela editora Gallimard de Paris em 1981, que atesta não só o apreço e o amor filial, mas a admiração profissional de um ser humano por outro. Em outro de seus livros, intitulado Films, Minha vida e meus filmes, Jean Renoir declara: "passei minha vida tentando determinar a influência de meu pai sobre mim" (2005, p. 15).

Na exposição, há citações evidentes, como em seus filmes onde Jean Renoir inclui uma demorada cena de duas mulheres com trajes do século XIX andando suavemente numa canoa em um rio, como que dando movimento a telas de Monet, Morissot ou do próprio Renoir.
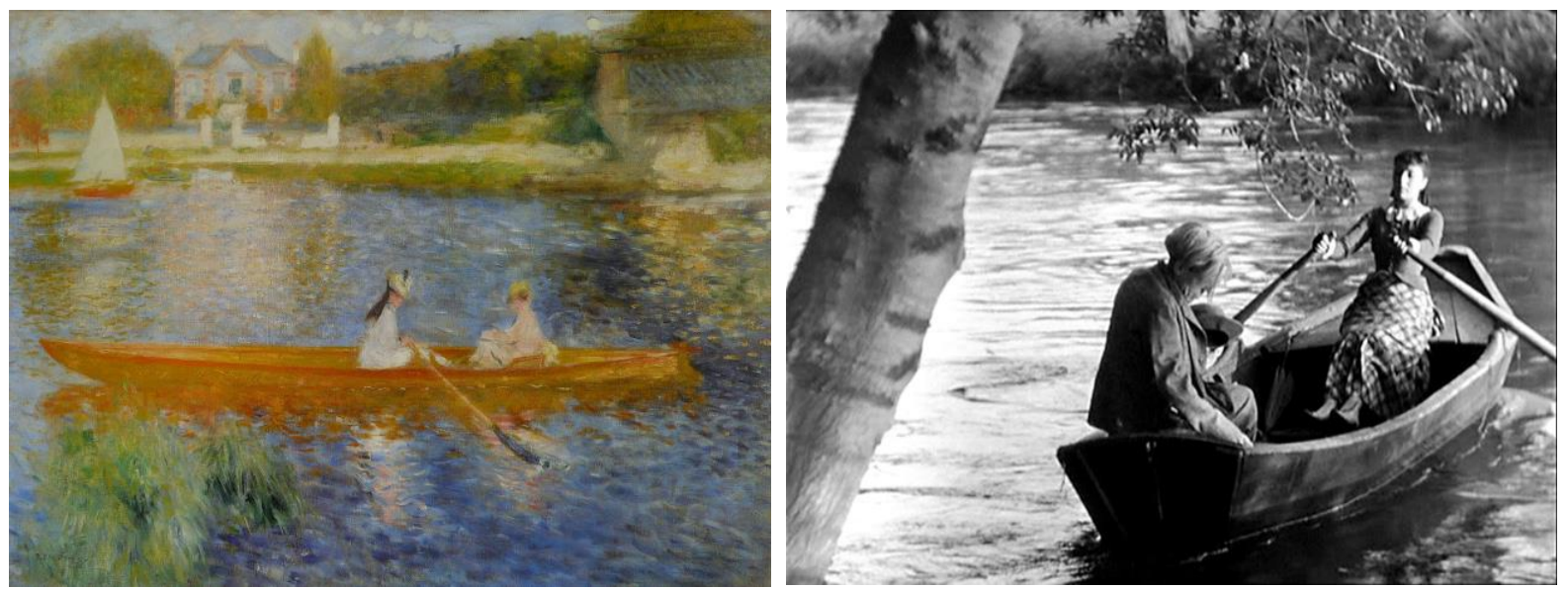

Figura 2 - La Yole (1875), pintura de Pierre-Auguste Renoir e cena de Partie de campagne (1936), filme de Jean Renoir. Fonte: Wikimedia Commons. Disponível em:

https://commons.wikimedia.org/wiki/File: Pierre-Auguste_Renoir_-_La_Yole.jpg; Senses of Cinema. Disponível em: http://sensesofcinema.com/2010/cteq/partie-de-campagne. Acesso em: fev. 2019. 
Outra citação evidente acontece após uma cena interna, em um bar, onde dois homens conversam em uma mesa junto à janela e, de repente a janela se abre e no jardim se vê a obra de Renoir Pai, La balançoire, "O balanço", modificada, com duas mulheres no balanço ao invés de uma, mas com os mesmos trajes de época; o movimento e os sons conferem à cena a alegria da diversão em um jardim de Montmartre, sentimento que só se pode perceber por ter se dado vida à cena. É impactante. Estaria Renoir Filho complementando a intencionalidade do pai, agregando a alegria que a estaticidade da pintura dificulta expressar?
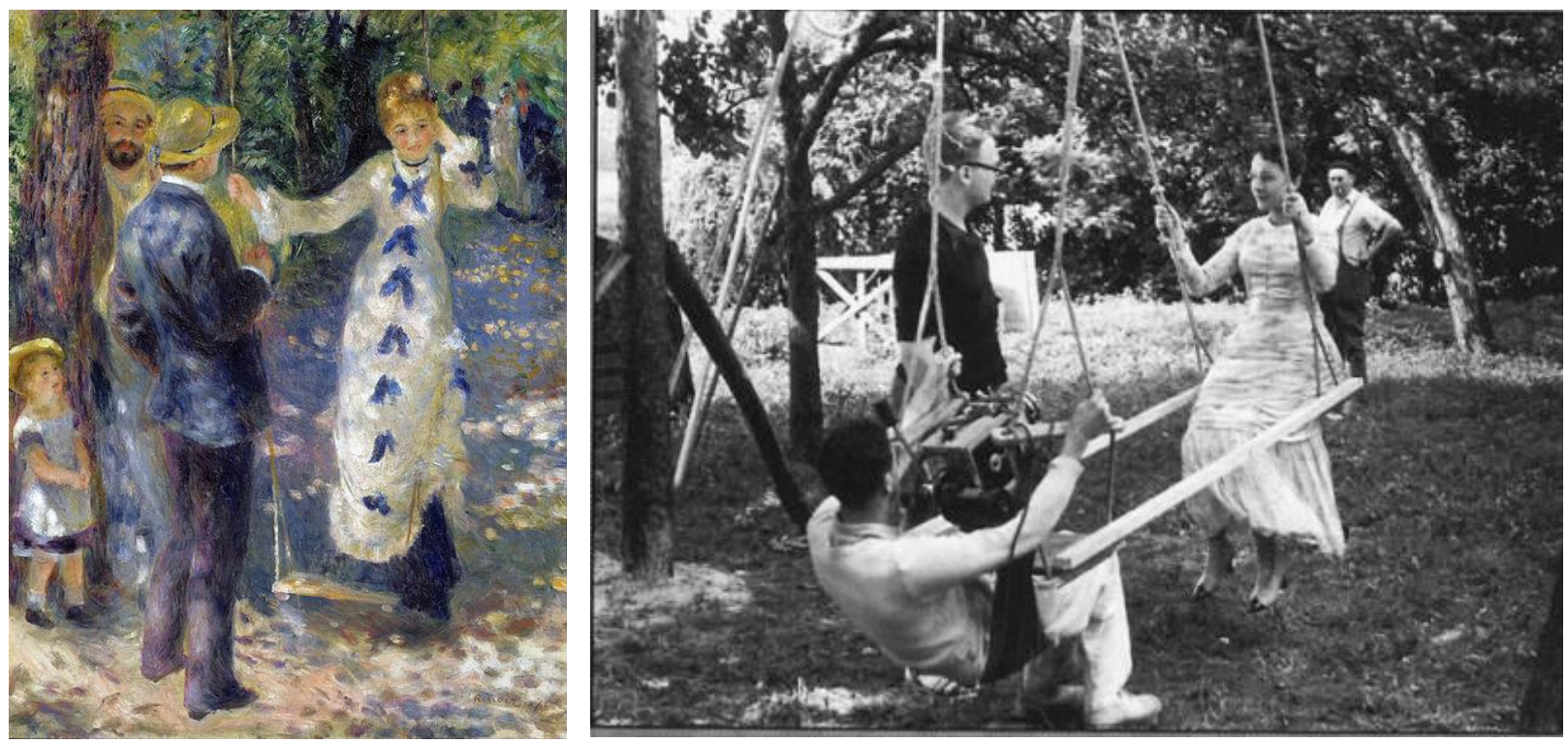

Figura 3 - La balançoire (1876), pintura de Pierre-Auguste Renoir e foto da filmagem de Partie de campagne (1936), filme de Jean Renoir. Fonte: Wikimedia Commons.

Disponível em: https://commons.wikimedia.org/wiki/File: Swing-Renoir.jpeg;

Ouvre les yeux. Disponível em: http://ouvre-les-

yeux.fr/unepartiedecampagnejeanrenoir1936labalancoireimpressionniste-1/. Acesso em: fev. 2019.

Relações entre a produção de pai e filho ficam mais evidentes, a começar pelo sobrenome; mas as intertextualidades não se devem apenas aos laços genéticos. Antes, o meio social, o espírito de época interferem e, é claro, o ambiente e situações familiares, que eram abertos à intelectualidade francesa, tanto artistas visuais quanto escritores. Isto se observa em outros processos intertextuais levados a efeito por Jean, não apenas em relação ao seu pai, como na adaptação de romances de notáveis escritores franceses, como Guy de Maupassant, Émile Zola e Honoré Mirabeau, para roteiros de seus filmes, em processos de tradução da linguagem verbal para a audiovisual. E quanto à visualidade, igualmente seu pai não é a única fonte de intertextualidade, pois também há evocações a Henri de ToulouseLautrec, Henri Matisse e Raoul Dufy, além de André Derain, Man Ray e Georges Braque. No 
caso de Jean Renoir, parece que o que ele queria deixar registrado, nas suas obras, era o espírito de uma época que ele viveu parcialmente e que lhe fugia, ensejando uma nostalgia de época.

Assim, cenários, colorido outonal, figurinos e hábitos, como andar de canoa ou brincar em balanços, tudo contribui para a inter-relações visuais entre a obra de pai e filho, ou da obra do filho com o período em que viveu seu pai. À publicação Cahiers du Cinéma (apud MUSÉE D'ORSAY), "Cadernos do Cinema", Renoir Filho declarou, em 1979 que

se certas passagens e certos figurinos podem lembrar quadros do meu pai, isto se dá por duas razões: primeiro, porque aquilo se passa em uma época e lugares onde meu pai trabalho muito, na época da sua juventude; depois, é porque sou filho de meu pai e todos são forçosamente influenciados pelos pais.

Aos estudos de intertextualidades interessa verificar as similaridades, não ignorando as diferenças. O que as modificações operadas estão a nos propor? Diferentes modos de vida? Diversificadas maneiras de ver? Novas possibilidades de sentir? Que mudanças a assinatura de Jean Renoir imprimiu na matéria prima que tomou de seu pai?

Anterior a isto, no século passado, as presenças intertextuais chamadas de influências, coincidências, ou inspirações nem sempre eram bem vistas. Tanto que o cineasta François Truffaut, expoente do movimento francês nouvelle vague, ou "nova onda", reconheceu publicamente que a história do cinema tinha uma dívida para com Jean Renoir, pois creditava a ele ser o precursor dessa estética filmográfica. Reconhecer uma dívida significa admitir, no próprio meio, a ausência de reconhecimento.

$\mathrm{Na}$ contemporaneidade, ao contrário, as lembranças e evocações de obras anteriores deixam de ser romantizadas como meras inspirações e passam a ser assumidas ostensivamente como apropriação, pastiche, paródia. E é nas dobras das diferenças, nas omissões, acréscimos, deslocamentos e alterações que se aninham os efeitos de sentido do trabalho de recriação.

Ribeiro (2008) afirma de modo sintético o que vem a ser este novo paradigma, na verdade, apontado por Duchamp no seu ready made emblemático, e ele também, o paradigma, apropriado por produtores de arte principalmente a partir da segunda metade do século XX:

Foram muitos os artistas que procuraram por imagens ou ideias prontas, influenciados pelas teorias pós-estruturalistas de Roland Barthes. Mas é partir dos noventa que um número cada vez maior de artistas interpreta, reproduz ou apropriase de obras, ideias, imagens, objetos, produtos ou elementos culturais, como uma resposta à multiplicação da oferta cultural, e mais indiretamente, à inclusão dentro do mundo da arte de formas até então ignoradas ou depreciadas. (RIBEIRO, 2008, p.796-797). 
Assim considerando, percebe-se que o fenômeno linguístico que é a intertextualidade, seja no modo de apropriação, interpretação, citação ou outro nome que se queira dar às relações analógicas entre textos visuais, sincréticos ou interlinguísticos, pois eles são muitos, cada vez mais se faz presente na arte contemporânea, para dessacralizar a arte, ou para promover uma crítica social, ou para ser objeto de autocrítica da arte, estas sendo algumas entre tantas possibilidades. Além do mais, está subjacente a reflexão sobre a sustentabilidade do planeta, questionando-se a produção capitalista incontrolável de supérfluos. Não basta, no universo, tudo o que nele já há? Não é possível explorar melhor o que se tem, reaproveitando, num sentido amplo?

Tais estratégias de apropriação das formas visuais existentes representam uma reação frente à superprodução de imagens no mundo. A superprodução já não é vivida como um problema, mas como um sistema cultural. (RIBEIRO, 2008, 797).

As relações de analogias entre as produções do pintor impressionista Pierre-Auguste Renoir e de seu filho, o escritor, ator e cineasta Jean Renoir foram tomadas como objeto empírico para estudo de um objeto teórico maior, a intertextualidade, a partir da exposição Renoir Père et Fils, que teve lugar no Musée D’Orsay em Paris, do final de 2018 ao início de 2019.

O que se observou é que Renoir Filho nunca contestou, ao contrário, a influência de seu pai. Por outro lado, o ambiente cultural fértil e sensível, povoado por escritores e pintores franceses da época áurea da intelectualidade local, propiciou que ele estabelecesse pontos de contato não apenas com a obra de seu pai, mas com as de outros pintores e escritores.

Do mesmo modo, soube-se que, inicialmente, a obra de Jean Renoir não foi compreendida pelo público nem bem aceita pela crítica e somente a vida longa e a árdua batalha para se firmar, por meio de publicações nas quais tentava se colocar, possibilitou que seu trabalho fosse reconhecido: recebeu um Oscar em 1975, e em 1976 recebeu uma condecoração do Ministério de Cultura da França, três anos antes da sua morte.

O que se percebe, em termos de diálogos entre trabalhos artísticos, é que muitos criadores de imagens lançam mão de manifestações anteriores, por razões distintas, que oscilam da crítica à homenagem. Como exemplo grande parte das obras de Vincent van Gogh (1853-1890) repetiam composições de Jean-François Millet (1914-1875), inclusive com a manutenção dos títulos, mas não das cores e pinceladas, assim como Delacroix buscou "inspiração" em obras de Rubens; e Manet e Degas nas de Velázquez. Isto não é um fenômeno exclusivamente contemporâneo, mas está presente com mais frequência na arte contemporânea. Assim sendo, se algumas insinuações de uma espécie de plágio pairavam sobre sua obra, hoje Jean Renoir não teria problemas com sua poética intertextual; ou, de outro modo, hoje ele pode ser considerado não apenas precursor da nouvelle vague francesa, 
mas também um dos precursores do uso deste procedimento na arte contemporânea, no que toca a apropriações, citações, enfim, criações entremeadas de trabalhos anteriores.

Por outro lado, resta ainda um motivo para que se continue estudando as intertextualidades: além de se identificar as similaridades entre manifestações, a seguir, também importa buscar as diferenças, para que se observe a existência de mudanças operadas em hiatos de tempo e de espaço, bem como seus respectivos sentidos para os tempos distintos e para a arte.

A grandiosidade das obras de ambos os membros da família Renoir tem determinado investigações e explorações diversas. Renoir Pai, talvez por ter decorrido mais tempo de sua existência, e mesmo dada a publicação de sua biografia por seu filho Jean, é o mais conhecido. Mas, a diversificada produção de Renoir Filho, mesmo tendo ele também escrito sobre sua vida e seus filmes, ainda oferece muito a ser explorado, tanto na perspectiva das relações intertextuais, mas ainda sob outros pontos de vista, como da política, da sociologia, da psicologia, da semiótica, e mesmo, especificamente, da linguagem cinematográfica.

As inter-relações entre a obra do cineasta Jean Renoir e de seu pai, Pierre-Auguste, merecem análises mais acuradas e com maior aprofundamento. Poderia ser objeto de dissertação ou tese. O que se pretendeu aqui nesta síntese, foi mostrar para um público maior, especialmente para o de língua portuguesa, esse potencial já conhecido, mas sobejamente evidenciado pelo Musée D'Orsay, ou seja, trazer para discussão o pouco que pode ser depreendido de uma visitação a uma exposição de arte, sob a perspectiva dos dois criadores e sob o ponto de vista das relações intertextuais possíveis entre a pintura e o cinema.

\section{Referências}

BARTHES, Roland. Théorie du texte et intertextuaité. In: RABEAU, Sophie. L'Intertextualité. Paris: Flammarion, 2002.

FEIST, Peter H. Pierre-Auguste Renoir 1841-1919: um sonho de harmonia. São Paulo: Taschen, 1990.

FIORIN, José. Luiz. Introdução ao pensamento de Bakhtin. São Paulo: Ática, 2008.

GENETTE, Gérard. La transtextualité ou l'intertextualité redéfinie. In: RABAU, Sophie.

L'Intertextualité. Paris: Flammarion, 2002.

HOLZWARTH, Hans Werner (org). Arte Moderna 1870-2000. São Paulo: Taschen, 2012.

KRISTEVA, Julia. L'acte de naissance de l'intertextualité ou l'espace de la

signification. In: RABAU, Sophie. L'Intertextualité. Paris: Flammarion, 2002.

MUSÉE D'ORSAY. Renoir Père et Fils: visite de l'exposition. Paris: nov. 2018 - jan. 2019.

OLIVEIRA, Ana Claudia. Neolítico: Arte Moderna. São Paulo: Perspectiva, 1987.

RENOIR, Jean. Ma vie et mes films. Paris: Flammarion, 2005.

RIBEIRO, Virgínia Cândida. Apropriação na arte contemporânea: colecionismo e memória. In:

MAKOWIECKY, Sandra; RAMALHO E OLIVEIRA, Sandra. Panorama da Pesquisa em Artes Visuais: 
Anais do $17^{\circ}$ Encontro Nacional da Associação Nacional de Pesquisadores em Artes Plásticas /ANPAP. Florianópolis: UDESC, 2007.

TARANILLA, Carlos Javier. Breve Historia del Arte. Madrid: Ediciones Nowtilus, 2017.

WEBER, Patrick. Histoire de l'Art. Paris: Librio, 2009. 